\title{
PENERAPAN MODEL PBM UNTUK MENINGKATKAN KINERJA DAN KEMAMPUAN BERPIKIR KRITIS SISWA SMA
}

\author{
Dini Dwi Lestari ${ }^{1 *}$, Irwandi Ansori ${ }^{1}$, Bhakti Karyadi ${ }^{1}$ \\ ${ }^{1}$ Program Studi Pendidikan Biologi, Fakultas Keguruan dan Ilmu Pendidikan, Universitas Bengkulu \\ E-mail: dinidwi22@gmail.com
}

\begin{abstract}
Abstrak
Penelitian ini bertujuan untuk meningkatkan aktivitas guru, kinerja, dan kemampuan berpikir kritis siswa pada materi Sistem Ekskresi di kelas XIIPA3 SMA Negeri 1 Kota Bengkulu dengan menerapkan model Pembelajaran Berbasis Masalah. Penelitian ini merupakan penelitian tindakan kelas yang dilakukan dalam dua siklus. Masing-masing siklus terdiri dari 4 tahap yaitu : tahap perencanaan, pelaksanaan, pengamatan dan refleksi. Subjek penelitian ini adalah guru dan seluruh siswa kelas XIIPA3 SMA Negeri 1 Kota Bengkulu yang berjumlah 33 orang. Metode yang digunakan adalah metode deskriptif. Teknik pengumpulan data aktivitas guru dan kinerja siswa adalah teknik observasi, menggunakan lembar observasi aktivitas guru dan lembar observasi penilaian kinerja. Adapun teknik yang digunakan untuk mengumpulkan data kemampuan berpikir kritis yaitu tes tertulis menggunakan lembar tes berpikir kritis. Hasil penelitian menunjukkan adanya peningkatan aktivitas guru, kinerja dan kemampuan berpikir kritis siswa. Rata-rata skor aktivitas guru pada siklus I yaitu 28 (baik) meningkat di siklus II menjadi 30 (baik). Kinerja siswa mengalami peningkatan yaitu pada siklus I 57,25\% dengan kriteria cukup pada siklus II meningkat menjadi $72,5 \%$ dengan kriteria baik. Hasil kemampuan berpikir kritis pada siswa di siklus I memperoleh persentase klasikal 59,39\% dengan kriteria cukup kritis, di siklus II meningkat menjadi $73,33 \%$ dengan kriteria kritis. Dapat disimpulkan bahwa penerapan model pembelajaran berbasis masalah dapat meningkatkan aktivitas guru, kinerja dan kemampuan berpikir kritis siswa pada materi sistem ekskresi di kelas XIIPA3 SMA Negeri 1 Kota Bengkulu.
\end{abstract}

Kata kunci: Pembelajaran Berbasis Masalah, Kinerja dan Kemampuan berpikir kritis, Biologi SMA

\begin{abstract}
This research aims to improve the teacher activity, performance and critical thinking skills of students on the material Excretion System in class XI IPA3 SMA Negeri 1 Kota Bengkulu by applying ProblemBased Learning model. This study is a classroom action research that conducted in two cycles. Each cycle consists of four stages: planning, implementation, observation and reflection. The subjects of this study are teachers and all students of class $\mathrm{XI}_{\text {IPA3 }}$ SMA Negeri 1 Kota Bengkulu total 33 people. The method is using descriptive method. Techniques for collecting teacher activity data and performance using observation techniques using teacher activity observation sheets and performance appraisal observation sheets. The technique used to collect critical thinking ability data is a written test using critical thinking test sheets. The result of the research shows that there is an increase in teacher activity, performance and critical thinking ability of the student's. The average score of teacher activity in cycle I is 28 (good) increased cycle II into 30 (good). Student performance has increased that is at cycle I 57,25\% with enough criterian, increase in cycle II become $72,5 \%$ with good criterian. The result of student's critical thinking ability in cycle I obtained classical percentage of $59,39 \%$ with critical enough criterian, increased in cycle II to $73,33 \%$ with criterian critical. It can be concluded that the application of problem-based learning model can improve teacher activity, performance and critical thinking ability of students on excretory system material in class $\mathrm{XI}_{\text {IPA3 }}$ SMA Negeri 1 Kota Bengkulu.
\end{abstract}

Keywords: Problem Based Learning, Performance and Critical Thinking Ability, High School Biology 


\section{PENDAHULUAN}

Kemajuan pendidikan di Indonesia diupayakan melalui pembangunan pendidikan formal di berbagai jenjang, mulai dari pendidikan dasar, menengah, sampai pendidikan tinggi yang diharapkan mampu mencapai fungsi Pendidikan Nasional, seperti yang tertera dalam Undang-undang Nomor 20 Tahun 2003 yaitu berfungsi mengembangkan kemampuan dan membentuk watak serta peradaban bangsa yang bermartabat dalam rangka mencerdaskan kehidupan bangsa. Salah satu pembangunan yang dilakukan oleh pemerintah adalah melalui pengembangan kurikulum.

Menurut Daryanto (2014:4) salah satu prinsip pengembangan kurikulum yai-tu, kurikulum dikembangkan atas dasar kesadaran bahwa ilmu pengetahuan, budaya, teknologi, dan seni berkembang secara dinamis. Oleh karena itu konten kuri-kulum harus selalu mengikuti dan memanfaatkan secara tepat hasil ilmu pengetahuan dan teknologi agar dapat mengi-kuti perkembangan tersebut.

Kurikulum 2013 merupakan salah satu bentuk perubahan yang dilakukan oleh pemerintah yang bertujuan untuk mengikuti perkembangan dan mempersiap-kan tuntutan pendidikan abad 21. Pende-katan yang digunakan pada kurikulum ini yaitu pendekatan saintifik. Tujuan dari pendekatan tersebut untuk meningkatkan kemampuan intelektual khususnya keterampilan berpikir tingkat tinggi (Hosnan, 2014:36). Keterampilan berpikir tingkat tinggi yang diterjemahkan dari Higher Or-der Thinking Skills (HOTS) adalah kegiatan berpikir yang melibatkan proses kognitif dan merupakan suatu kegiatan yang di da-lamnya terdapat aktivitas kemampuan berpikir kritis (critical thinking) (Amri, 2015 :155).

Kemampuan berpikir kritis perlu dipertimbangkan dalam pelaksanaan proses pembelajaran terutama pada pembelajaran biologi, karena seperti yang dicantumkan dalam Permendikbud Nomor 24 Tahun 2016
Kompetisi Dasar pada materi Sistem Ekskresi 3.9 yaitu menganalisis hubungan antara struktur jaringan penyusun organ pada sistem ekskresi dalam kaitannya dengan bioproses dan gangguan fungsi yang dapat terjadi pada sistem ekskresi manusia. Kegiatan menganalisis seperti ini sangat erat kaitannya dengan kegiatan atau kemampuan siswa dalam menemukan konsep dan pengetahuan terkait materi, sehingga dibutuhkanlah kemampuan salah satunya kemampuan berpikir kritis untuk mencapai tujuan melalui penerapan model tertentu.

Berdasarkan hasil wawancara de-ngan guru biologi kelas XIIPA3 SMA Negeri 1 Kota Bengkulu, persentase keterampilan berpikir kritis siswa secara klasikal pada mata pelajaran biologi diperkirakan baru mencapai $60 \%$. Hal tersebut dikarenakan proses pembelajaran yang dilakukan oleh guru biologi dalam upaya peningkatan keterampilan berpikir kritis tampaknya belum dikembangkan secara optimal walaupun dalam proses pembelajaran guru telah menggunakan metode dan media yang disesuaikan dengan materi, namun di sisi lain guru juga menyadari bahwa guru belum melakukan pembelajaran sesuai sintaks model pembelajaran yang harusnya diterapkan oleh guru saat menyampaikan materi untuk melatih keterampilan berpikir kritis siswa.

Johnson(2007:184) mengemukakan bahwa berpikir kritis merupakan kegiatan yang sangat penting untuk dikembangkan, karena tujuan dari berpikir kritis adalah untuk mencapai pemahaman yang mendalam, sehingga mampu mengatasi permasalahan yang ditemukan dalam kehidupan sehari-hari. Oleh sebab itu, guru diharapkan mampu mengaktifkan serta mengembangkan kemampuan berpikir kritis siswa melalui proses pembelajaran. Selain itu penggunaan LKS atau LDS juga belum terlalu optimal karena guru masih terpaku pada buku dari penerbit, dan tidak merancang LKS atau LDS sesuai indikator berpikir kritis.

Berdasarkan permasalahan tersebut, maka peneliti melakukan penelitian tindakan kelas dengan menerapkan model 
pembelajaran yang memiliki ciri mendorong pengembangan kemampuan berpikir kritis. Adapun model yang sesuai diterapkan untuk mengatasi pembelajaran tersebut yaitu model Pembelajaran Berbasis Masalah (PBM).

Menurut Daryanto (2014:30), pembelajaran yang berorientasi pada masalah akan mengembangkan keterampilan berpikir tingkat tinggi, selain itu penerapan model PBM akan menghasilkan pembelajaran yang aktif sesuai sintaks PBM yang akan menumbuhkan isu dan berujung pada pertanyaan serta keinginan peserta didik dalam menyelididki dan memecahkan permasalahan tersebut. Tujuan penelitian ini adalah untuk mendeskripsikan aktivitas guru, dan meningkatkan kinerja dan kemampuan berpikir kritis siswa kelas XI IPA3 SMA Negeri 1 Kota Bengkulu menggunakan model PBM pada materi Sistem Ekskresi.

\section{METODOLOGI PENELITIAN}

Penelitian ini merupakan penelitian tindakan kelas (classroom action research) yang dilakukan dalam dua siklus. Metode penelitian yang digunakan dalam penelitian ini adalah metode deskriptif. Menurut Darmadi (2014: 185), metode deskriptif digunakan untuk memecahkan dan menjawab permasalahan yang sedang dihadapi pada situasi sekarang dengan cara mendeskripsikan atau menggambarkan data yang terkumpul. Pada penelitian ini, deskripsi yang ingin diperoleh adalah aktivitas guru, kinerja dan kemampuan berpikir kritis siswa. Subyek pada penelitian ini adalah guru dan seluruh siswa kelas XI IPA3 SMA Negeri 1 Kota Bengkulu tahun ajaran 2016/2017 yang berjumlah 33 orang. Penentuan subyek siswa dilakukan secara convenience sampling. Zuriah (2009:142) menjelaskan bahwa convenience sampling merupakan penetapan subyek atau sampel berdasarkan kemudahan atau ketersediaan subyek itu sendiri. Teknik yang digunakan untuk mengumpulkan data dalam penelitian adalah observasi dan tes.

Teknik obsevasi digunakan untuk mengumpulkan data aktivitas guru dan kinerja. Aktivitas guru akan diobservasi oleh tiga orang pengamat dengan menggunakan lembar observasi dalam bentuk skala penilaian yaitu baik, cukup dan kurang. Kinerja siswa langsung diobservasi dan dinilai oleh guru peneliti selama proses pembelajaran berlangsung menggunakan lembar penilaian kinerja yang disusun berdasarkan dua indiaktor berpikir kritis yaitu; 1) membangun keterampilan dasar dan menentukan strategi, dan 2) taktik yang dilakukan oleh siswa selama proses pembelajaran. Teknik yang digunakan untuk mengukur kemampuan berpikir kritis adalah tes dengan menggunakan instrumen berupa lembar tes kemampuan berpikir kritis. Soalsoal uraian pada lembar tes dirumuskan berdasarkan indikator kemampuan berpikir kritis yaitu, kemampuan untuk memberikan alasan, menarik kesimpulan sesuai fakta, membuat dan menentukan hasil pertimbangan berdasarkan penerapan fakta dan menentukan suatu tindakan (Muhfahroyin, 2009: 89).

Data hasil observasi aktivitas guru akan dianalisis dengan menentukan nilai ratarata yang diperoleh dari 3 orang pengamat. Penentuan kriteria rerata hasil pengamatan dilakukan dengan menentu- kan kisaran skor kriteria baik, cukup, dan kurang.

Menurut Sukardi (2012) meng- hitung kisaran skor menggunakan rumus:

$$
\mathrm{Rk}=\frac{\text { skor tertinggi-skor terendah }}{\text { jumlah kriteria }}
$$

Keterangan:

Skor tertinggi $=$ jumlah butir pengamatan $\mathrm{x}$ skor maksimum setiap butir

Skor terendah $=$ jumlah butir pengamatan $\mathrm{x}$ skor minimum setiap butir

Kriteria rerata skor aktivitas guru dapat dilihat pada Tabel 1.

Tabel 1. Kriteria Rerata Skor Aktivitas Guru

\begin{tabular}{cc}
\hline Kriteria & Interval \\
\hline Baik & $24-30$ \\
Cukup & $17-23$ \\
Kurang & $10-16$ \\
\hline
\end{tabular}

kinerja siswa dianalisis dengan menentukan rata-rata skor, persentase dan 
kriteria masing-masing indikator dan kla-sikal. Kriteria kinerja berpikir kritis dapat dilihat pada Table 2. Data hasil tes kemam-puan berpikir kritis siswa akan dianalisis dengan cara menghitung persentase seca-ra klasikal dan menentukan kriteria persen-tase. Adapun rumus persentase yang digu-nakan untuk menghitung persentase kiner-ja dan kemampuan berpikir kritis menggu-nakan rumus Sudijono (2014:43), yaitu:

$$
\mathrm{P}=\frac{\sum X}{N} \mathrm{X} 100 \%
$$

Keterangan:

$\mathrm{P} \quad=$ Angka persentase

$\Sigma \mathrm{x}=$ Jumlah nilai yang diperoleh seluruh kelompok siswa

$\mathrm{N}=$ Jumlah seluruh kelompok siswa

Tabel 2. Persentase dan Kriteria Kinerja Siswa

\begin{tabular}{cc}
\hline Persentase & Kriteria \\
\hline $81 \%-100 \%$ & Sangat Baik \\
$66 \%-80 \%$ & Baik \\
$56 \%-65 \%$ & Cukup \\
$41 \%-55 \%$ & Kurang \\
$0-40 \%$ & Tidak Baik \\
\hline & (Arikunto, 2016:281)
\end{tabular}

berpikir kritis secara klasikal adalah sebagai berikut:

$$
\mathrm{P}=\frac{\sum X}{N} \mathrm{X} 100 \%
$$

Keterangan:

$\mathrm{P}=$ Angka persentase

$\Sigma \mathrm{x}=$ Jumlah nilai yang diperoleh seluruh siswa

$\mathrm{N}$ = Jumlah seluruh siswa

Data yang didapat dianalisis secara klasikal dengan menghitung persentase nilai siswa dan menetukan kriteria persentase disesuaikan dengan kriteria seperti pada Tabel 3 yang tertera di bawah ini:

Tabel 3. Persentase dan Kriteria Kemampuan Berpikir Kritis

\begin{tabular}{cc}
\hline Persentase & Kriteria \\
\hline $81 \%-100 \%$ & Kritis Sekali \\
$66 \%-80 \%$ & Kritis \\
$56 \%-65 \%$ & Cukup Kritis \\
$41 \%-55 \%$ & Kurang Kritis \\
$0-40 \%$ & Tidak Kritis \\
\hline
\end{tabular}

\section{HASIL DAN PEMBAHASAN}

\section{Aktivitas Guru}

Pembelajaran berbasis masalah (PBM) merupakan model pembelajaran yang menjadikan permasalahan sebagai starting point atau point utama untuk memulai pembelajaran. Permasalahan yang diangkat adalah permasalahan yang ada di dunia nyata atau kehidupan sehari-hari. Rusman (2014:230) menjelaskan bah -

wa masalah yang ditampilkan pada PBM mampu mendorong keseriusan, inkuiri, dan berpikir dengan cara yang bermakna dan sangat kuat. Oleh sebab itu hasil penerapan model PBM pada proses pembelajaran sistem ekskresi dinilai baik, dilihat dari peningkatan nilai aktivitas guru, kinerja siswa, serta meningkatkan persentase kemampuan berpikir kritis siwa kelas XI $\mathrm{XI}_{\text {PA3 }}$ SMA Negeri 1 Kota Bengkulu. Adapun hasil dari aktivitas guru setelah menerapkan model pembelajaran berbasis masalah dapat dilihat pada Tabel 4

Pada Tabel 4, diketahui bahwa skor pada siklus I dari 28 dengan kriteria baik, meningkat di siklus II menjadi 30 dengan kriteria baik. Hal tersebut menandakan bahwa pembelajaran menggunakan model pembelajaran berbasis masalah berlang-sung efektif.

Tabel 4. Data Hasil Observasi Aktivitas Guru

\begin{tabular}{ccc}
\hline \multirow{2}{*}{ Siklus } & \multicolumn{2}{c}{ Aktivitas Guru } \\
\cline { 2 - 3 } & Rata-rata & Kriteria \\
\hline I & 28 & Baik \\
II & 30 & Baik \\
\hline
\end{tabular}

Penelitian ini menggunakan model PBM yang merujuk pada tahapan atau sintaks, yaitu: 1) orientasi siswa pada masalah; 2)mengorganisasi siswa untuk belajar; 3)membimbing pengalaman individual/ kelompok; 4)mengembangkan dan menyajikan hasil karya; 5)menganalisis dan mengevaluasi proses pemecahan masalah (Ibrahim, 2012:24). 
Masing-masing tahapan terdiri dari beberapa aspek atau kegiatan yang dilaku-kan oleh guru, berikut adalah penjabaran aktivitas guru berdasarkan sintaks atau tahapan model PBM dalam proses pem-belajaran yang telah dilaksanakan:

\section{a. Orientasi siswa pada masalah}

Pada kegiatan ini dinilai baik oleh pengamat karena guru menjelaskan secara keseluruhan tujuan pembelajaran kepada siswa menggunakan media power point dan tujuan yang disampaikan menunjuk-kan adanya indikator pemecahan masalah. Menjelaskan tujuan pembelajaran sangat penting dilakukan agar siswa dapat memahami bahwa apa saja pengetahuan yang perlu dicapai dalam proses pembelajaran. Hal ini selaras dengan pendapat Kosasih (2014:46), yang menyatakan bahwa menjelaskan tujuan pembelajaran penting dilakukan, karena apabila siswa sudah mengetahui tujuan pembelajaran, siswa akan menjadi lebih terarah dalam proses pembelajaran.

Selain menjelaskan tujuan pembelajaran, pada tahap orientasi masalah guru juga mengajukan fenomena untuk memunculkan masalah. Fenomena yang dimunculkan adalah fenomena masalah yang terjadi di sekitar siswa. Pada siklus I guru mengajukan fenomena berupa perbedaan warna urine manusia, sedangkan pada siklus II guru mengajukan masalah saat panas kita mudah berkeringat. Memunculkan masalah adalah tahap yang amat penting, karena PBM tidak dapat berlangsung tanpa masalah. Menurut Ibrahim (2012:39), masalah yang baik adalah masalah yang muncul dari siswa yang belajar, sehingga siswa mempunyai rasa memiliki terhadap masalah tersebut.

Tahap orientasi masalah ditutup dengan kegiatan guru memotivasi siswa untuk terlibat dalam pemecahan masalah. Pada siklus I, guru belum terlalu optimal dalam memotivasi siswa agar terlibat dalam pemecahan masalah, guru hanya memotivasi sebagian kecil kelompok saja. Hal tersebut disebabkan guru belum meng-gunakan strategi bertanya yang baik untuk memancing siswa untuk terlibat dalam orientasi masalah, menurut penelitian yang dilakukan oleh Zukmadini (2014:27) bahwa strategi bertanya digunakan oleh pendidik untuk mencapai tujuan pembelajaran, karena dapat membuat peserta didik lebih aktif dalam menyampaikan pendapat, berdiskusi, menanggapi permasalahan, dan memberikan kesimpulan. Hal tersebut dijadikan refleksi oleh guru dan diperbaiki di siklus II. Sehingga pada siklus II, guru memotivasi seluruh kelompok siswa untuk terlibat dalam pemecahan masalah dan memberikan penguatan terhadap kelompok dengan menggunakan strategi bertanya yang baik sehingga siswa bersemangat dalam proses pembelajaran serta dapat memecahkan masalah yang sudah diajukan guru.

\section{b. Mengorganisasikan Siswa}

Tahap mengorganisasikan siswa yaitu terkait dengan persiapan siswa dalam melaksanakan kegiatan pembelajaran dalam kelompok. Pada siklus I guru menjelaskan seluruh prosedur kegiatan pembelajaran yang harus dilakukan oleh siswa dalam memecahkan masalah, khususnya prosedur kegiatan pada LKS. LKS yang digunakan pada siklus I yaitu LKS tentang uji urine. Seluruh bagian dari LKS, seperti alat dan bahan yang dibutuhkan hingga langkah kerja kegiatan dan pengisian di tabel hasil dijelaskan oleh guru secara sistematis. Pada siklus II guru menyampaikan prosedur lembar diskusi siswa (LDS) secara sistematis yang digunakan dalam pemecahan masalah mengenai kulit sebagai alat ekskresi.

Selain menjelaskan prosedur kegiatan dalam pembelajaran, guru mengarahkan kelompok siswa untuk membagi tugas setiap anggota kelompok dalam melaksanakan kegiatan pembelajaran. Aspek ini belum dilaksanakan secara optimal oleh guru di siklus I, karena guru belum mampu mengarahkan seluruh kelompok untuk membagi tugas ke masing-masing anggota kelompoknya, sehingga 3 kelompok lainnya 
bekerja tanpa arahan yang optimal dalam pembagian tugas oleh guru secara spesifik.

Menurut Ibrahim (2012:21) salah satu tujuan dari PBM adalah untuk mengembangkan kemampuan kerjasama siswa, karena dalam kegiatan memecahkan masalah siswa membutuhkan teman untuk bekerja sama. Pembagian tugas bertujuan agar seluruh anggota kelompok menjadi aktif dalam pembelajaran dan diskusi. Pada siklus II guru berusaha memperbaiki aspek tersebut sesuai dengan refleksi untuk dapat mengarahkan seluruh kelompok siswa berbagi tugas ke sesama anggota kelompoknya.

\section{c. Membimbing pengalaman individual/ kelompok}

Kegiatan yang dilakukan oleh guru yaitu membimbing kelompok siswa mengumpulkan data atau informasi. Pada kegiatan ini guru sudah mampu membimbing seluruh kelompok siswa (6 kelom-pok) dengan memberikan arahan saat sis-wa mengalami kesulitan dalam mengum-pulkan data/informasi untuk pemecahan masalah, sehingga seluruh anggota dari masing-masing kelompok siswa bekerja-sama mengumpulkan data.

Aspek selanjutnya pada tahap membimbing pengalaman individual/ kelompok adalah membimbing kelompok siswa pada saat mengaitkan data hasil diskusi/ percobaan dengan konsep. Guru membimbing seluruh kelompok siswa (6 kelompok) dengan memberikan penjelasan terhadap kesulitan kelompok pada saat mengaitkan data hasil diskusi atau percobaan dengan konsep. Penjelasan yang diberikan tidak langsung menjawab pertanyaan atau ke-sulitan siswa, namun guru memancing sis-wa dengan memberikan pertanyaan arah-an, sehingga dapat melatih siswa untuk berpikir mandiri, dan mengarahkan pe-mikiran siswa pada solusi pemecahan ma-salah. Hal ini sesuai dengan Ibrahim (2012:44) yang menjelaskan bahwa bim-bingan yang diberikan harusnya tidak langsung menjawab pertanyaan siswa, namun tugas guru membimbing dengan cara mengajukan pertanyaan arahan sehingga siswa menemukan sendiri jawa-bannya.

\section{d. Mengembangkan dan mempresentasi- kan hasil karya}

Guru membimbing seluruh kelom-pok siswa dalam menyiapkan karya berupa jawaban dari kegiatan pemecahan ma-salah. Pada siklus I, guru membimbing sis-wa untuk menyiapkan hasil percobaan me-ngenai uji urine dan pada siklus II guru membimbing siswa berdiskusi mengenai kulit sebagai alat ekskresi. Pada kegiatan ini berjalan dengan baik, karena guru mampu membimbing dan mendatangi se-luruh kelompok siswa (6 kelompok) tanpa ada satupun kelompok yang tidak dibim bing.

\section{e. Menganalisis dan mengevaluasi proses pemecahan masalah}

Kegiatan yang dilakukan oleh guru yaitu membimbing siswa membuat kesim-pulan terkait penyelidikan yang siswa laku-kan pada materi sistem ekskresi. Pada ke-giatan ini telah berjalan dengan baik dimana guru membimbing seluruh kelom-pok siswa tanpa terkecuali untuk menarik kesimpulan sesuai materi pembelajaran pada siklus I yaitu sistem ekskresi pada ginjal dan siklus II sistem ekskresi pada kulit.

Pada tahap ini guru juga meng-arahkan siswa mengaitkan konsep yang diperoleh dengan kehidupan sehari-hari. Di siklus I, guru mengarahkan siswa untuk mengaitkan bahwa warna urine berbeda tergantung dengan makanan atau minum-an yang dikonsumsi (pola konsumtif), se-dang mengkonsumsi obat-obatan, akti-vitas yang dikerjakan, dan adanya indikasi penyakit. Sedangkan pada siklus II, guru mengarahkan siswa untuk mengaitkan bahwa fungsi kulit sebagai pengatur suhu tubuh yang menyebabkan kulit harus me-ngeluarkan keringat saat berada di ling-kungan panas ataupun sedang melakukan aktivitas berat seperti berolahraga. 
Kinerja dan Kemampuan Berpikir Kritis

Selain meningkatkan aktivitas guru, penerapan model PBM juga meningkatkan kinerja dan kemampuan berpikir kritis siswa kelas XIIPA3 SMA Negeri 1 Kota Bengkulu. Adapun data persentase dan kriteria kinerja siswa dapat dilihat pada Tabel 5.
Kinerja yang diukur pada penelitian ini adalah kegiatan yang dilakukan oleh siswa selama proses pembelajaran ber-dasarkan 2 indikator, yaitu membangun keterampilan dasar dan menentukan strategi dan taktik.

Tabel 5. Persentase dan Kriteria Kinerja Berpikir Kritis

\begin{tabular}{ccccc}
\hline \multirow{2}{*}{ Indikator } & \multicolumn{2}{c}{ Siklus I } & \multicolumn{2}{c}{ Siklus II } \\
\cline { 2 - 5 } & Persentase & Kriteria & Persentase & Kriteria \\
\hline $\begin{array}{c}\text { Membangun keterampilan } \\
\text { dasar }\end{array}$ & $52 \%$ & Cukup & $70 \%$ & Baik \\
$\begin{array}{c}\text { Menentukan startegi dan } \\
\text { taktik }\end{array}$ & $62,5 \%$ & Cukup & $75 \%$ & Baik \\
Rata-rata (Klasikal) & $57,25 \%$ & Cukup & $72,5 \%$ & Baik \\
\hline
\end{tabular}

Pada siklus I persentase kinerja siswa dengan indikator membangun keterampilan dasar memiliki persentase yaitu $52 \%$ dengan kriteria cukup. Hal ini disebabkan karena masih rendahnya kemampuan kinerja siswa untuk membuat kesimpulan yang mengaitkan dengan data dan tujuan kegiatan. Amri (2015:151) yang menjelaskan bahwa pentingnya keterampilan menyimpulkan karena merupakan bagian dari tahapan dimana menuntut pola pikir atau proses berpikir yang memperdayakan pengetahuannya sedemikian rupa untuk menghasilkan sebuah pemikiran atau pengetahuan yang baru. Setelah dilakukan refleksi, persentase indikator membangun keterampilan dasar mengalami peningkatan pada siklus II yaitu sebesar $70 \%$ dengan kriteria baik, persentase ini menunjukkan adanya peningkatan keterampilan siswa menjawab pertanyaan berpikir kritis dan membuat kesimpulan berdasarkan data dan tujuan kegiatan.

Pada indikator menentukan strategi dan taktik, aspek yang dinilai oleh guru adalah kemampuan berkomunikasi yang dilakukan oleh siswa melalui kegiatan presentasi pada saat diskusi kelas. Persentase pada indikator tersebut di siklus I yaitu sebesar $62,5 \%$ dengan kriteria cukup baik. Hal ini dikarenakan masih ada beberapa kelompok yang belum menguasai materi pada saat presentasi. Sehingga dilakukan refleksi untuk mengoptimalkan indikator kinerja siswa. Pada siklus II indikator menentukan strategi dan taktik mengalami peningkatan menjadi $75 \%$ dengan kriteria cukup. Peningkatan kinerja siswa di sertai dengan peningkatan kemampuan berpikir kritis siswa, hal ini dapat dilihat pada Tabel 6. Kemampuan berpikir kritis siswa secara klasikal pada siklus I mencapai 59,39\% dengan kriteria cukup kritis karena berada pada interval 55\%-65\%.

Tabel 6.Persentase Kriteria Kemampuan Berpikir Kritis secara Klasikal

\begin{tabular}{ccc}
\hline Siklus & $\begin{array}{c}\text { Persentase } \\
\text { Klasikal (\%) }\end{array}$ & Kriteria \\
\hline I & 59,39 & Cukup Kritis \\
II & 73,33 & Kritis \\
\hline
\end{tabular}

Persentase kemampuan berpikir kritis siswa masih jauh untuk mencapai kriteria kritis bahkan kriteria kritis sekali. Terkait dengan model PBM yang berorientasi pada masalah, peneliti menggunakan masalah untuk melatih kemampuan berpikir kritis siswa. Masalah atau kasus yang diberikan bisa dalam bentuk artikel yang disadur dari beberapa sumber. Artikel atau masalah yang digunakan dalam siklus I yaitu mengenai "Penderita Gagal Ginjal Meningkat, Pasien Cuci Darah 
Membludak". Secara umum siswa sudah mengetahui struktur dan bagian-bagian dari ginjal, akan tetapi siswa belum optimal untuk mencapai 2 dari 4 indikator berpikir kritis yaitu indikator menarik kesimpulan sesuai fakta dan menentukan suatu tindakan. Jawaban siswa pada lembar tes masih belum mampu mengaitkan dengan konsep, seperti: mengaitkan pola konsumtif dengan struktur dan fungsi serta gangguan pada bioproses. Hal tersebut juga dibuktikan dari kinerja siswa pada indikator membangun keterampilan dasar dengan membuat kesimpulan yang belum optimal.

Pada siklus II guru melakukan perbaikan dalam proses pembelajaran dengan membimbing siswa dalam mengembangkan dan menyajikan hasil karya. Guru peneliti memberikan masalah berupa kasus penyakit "Anhidrosis" yang terjadi pada kulit, persentase kemampuan berpikir kritis siswa secara klasikal mengalami peningkatan menjadi $73,33 \%$ dengan kriteria kritis. Siswa sudah mampu menjawab pertanyaan yang diberikan oleh guru berdasarkan 4 indikator kemampuan berpikir kritis, siswa mampu untuk memberikan alasan sesuai dengan kasus atau masalah yang diajukan, siswa mampu membuat dan menentukan hasil pertimbangan berdasarkan penerapan fakta seperti mengaitkan permasalahan pada kasus dengan struktur dan fungsi kulit sebagai alat ekskresi selain itu siswa juga mampu memberikan tindakan apa yang harus dilakukan terkait menjaga kesehatan sistem ekskresi.

Peningkatan kinerja dan kemampuan berpikir kritis tersebut tidak terlepas dari perbaikan kegiatan pembelajaran di siklus I yang dilakukan oleh guru menggunakan model PBM. Meskipun secara klasikal siswa sudah mampu mampu meningkatkan skor masing-masing pertanyaan berdasarkan 4 indikator, tetapi dianalisis dari jawaban siswa pada tiap siklus, siswa masih mengalami kesulitan untuk menjawab pertanyaan tes dengan indikator menarik kesimpulan sesuai fakta, yang merupakan salah satu aspek dari keterampilan menyimpulkan.

Dalam tahapan PBM, aspek keterampilan menyimpulkan sudah dilatih dalam sintaks yaitu mengembangkan dan mempresentasikan hasil karya. Hasil karya yang ditampilkan berupa jawaban LKS atau LDS yang sudah dikerjakan oleh siswa. Salah satu pertanyaan diskusi pada LKS adalah menyimpulkan kegiatan sesuai tujuan, tetapi ada beberapa jawaban dari kelompok siswa masih belum tepat dalam menyimpulkan kegiatan yang sudah dilakukannya, sehingga nilai siswa pada aspek menyimpulkan masih dirasa belum terlalu optimal walaupun mengalami peningkatan tiap siklusnya. Hal tersebut dibuktikan dari skor jawaban siswa pada soal dengan indikator tersebut yang masih tergolong rendah diantara indikator lainnya.

\section{PENUTUP \\ Simpulan}

Perbaikan pembelajaran dengan menerapkan model Pembelajaran Berbasis Masalah pada Materi Sistem Ekskresi dapat meningkatkan aktivitas guru, kinerja dan kemampuan berpikir kritis siswa kelas $\mathrm{XI}_{\text {IPA3 }}$ SMA Negeri 1 Kota Bengkulu. Ratarata skor aktivitas guru pada siklus I yaitu 28 (baik) meningkat disiklus II menjadi 30 (baik). Kinerja siswa pada siklus I yaitu $57,25 \%$ dengan kriteria cukup baik meningkat di siklus II menjadi 72,5\% dengan kriteria baik. Peningkatan kinerja ini diikuti oleh peningkatan kemampuan berpikir kritis siswa pada siklus I yaitu memperoleh persentase klasikal 59,39\% dengan kriteria cukup kritis, meningkat disiklus II menjadi $73,33 \%$ dengan kriteria kritis.

\section{Saran}

Berdasarkan penelitian yang telah dilakukan, diharapkan kepada guru mata pelajaran biologi kelas XI IPA3 SMA Negeri 1 Kota Bengkulu dapat menggunakan model 
Pembelajaran Berbasis Masalah sebagai salah satu alternatif dalam pembelajaran untuk diterapkan pada pembelajaran Biologi sebagai salah satu upaya meningkatkan aktivitas guru, kinerja dan kemampuan berpikir kritis siswa. Untuk penelitian lanjutan dalam menyusun perangkat pembelajaran terutama Lembar Kerja Siswa (LKS), Lembar Diskusi Siswa (LDS) dan lembar tes agar dapat menambah indikator kemampuan berpikir kritis yang akan diukur atau diteliti.

\section{DAFTAR PUSTAKA}

Amri, Sofan. 2015. Implementasi Pembelajaran Aktif dalam Kurikulum 2013. Jakarta: Prestasi Pustaka Jakarta

Arikunto, S. 2016. Dasar-dasar Evaluasi Pendidikan. Jakarta : PT. Bumi Aksara.

Darmadi, H. 2014. Metode Penelitian Pendidikan dan Sosial. Bandung : Penerbit Alfabeta.

Daryanto. 2014. Pendekatan Pembelajaran Saintifik Kurikulum 2013. Yogyakarta: Penerbit Gava Media.

Hosnan, M. 2014. Pendekatan Saintifik dan Kontekstual dalam Pembelajaran Abad 21. Bogor: Ghalia Indonesia.

Ibrahim, M. 2012. Pembelajaran Berbasis Masalah Edisi Kedua . Surabaya: Unesa University Press.

Johnson, E, B. 2007. Contextual Teaching and Learning(terjemahan). Bandung : Mizan Learning Center.

Kosasih, E. 2014. Strategi Belajar dan Pembelajaran Implementasi Kurikulum 2013 . Bandung: Penerbit Yrma Widya.

Muhfahroyin. 2009. Memberdayakan Kemampuan Berpikir Kritis Siswa Melalui Pembelajaran Konstruk- tivistik. Jurnal Pendidikan dan Pembelajaran (online) (http://journal.um.ac.id) diakses 10 februari 2017.

Permendikbud Nomor 24 Tahun 2016 tentang Kompetensi Inti dan Kompetensi Dasar Biologi SMA/MA (Lampiran 7).

Sukardi, H. M. 2012. Evaluasi Pendidikan. Jakarta: Bumi Aksara.

Undang-undang Nomor 20 Tahun 2003 tentang Sistem Pendidikan Nasional (salinan).

Zukmadini, Alif. 2014. Problem-Based Learning Melalui Lesson Study untuk Meningkatkan Keterampian Berpikir Kritis Mahasiswa Biologi. Malang : Universitas Negeri Malang.

Zuriah, N. 2009. Metodologi Penelitian Sosial dan Pendidikan. Jakarta: PT Bumi Aksara. 